\title{
Unstable Naturally Occurring Resistance to Antibiotics in Streptomyces
}

\author{
By R. F. FREEMAN* AND D. A. HOPWOOD \\ John Innes Institute, Colney Lane, Norwich NR4 7UH
}

(Received 16 January 1978)

INTRODUCTION

Two sets of observations suggested that extrachromosomal elements conferring antibiotic resistance might be widespread in streptomycetes. One was the evidence for plasmids affecting various other phenotypic properties in these organisms. Streptomyces coelicolor A3(2) contains a plasmid, SCP1, which acts as a conjugal sex factor and also codes for methylenomycin production and resistance (Kirby, Wright \& Hopwood, 1975; Wright \& Hopwood, 1976); less direct evidence implicates plasmids in the control of antibiotic production in Streptomyces kasugaensis (Okanishi, Ohta \& Umezawa, 1970), Streptomyces hygroscopicus (Kähler \& Noack, 1974) and Streptomyces venezuelae (Akagawa, Okanishi \& Umezawa, 1975), melanin production in Streptomyces scabies (Gregory \& Huang, 1964), S. venezuelae (Okanishi et al., 1970) and Streptomyces glaucescens (Baumann \& Kocher, 1976), and aerial mycelium production in S. venezuelae, S. kasugaensis, S. scabies (Okanishi et al., 1970) and Streptomyces alboniger (Redshaw et al., 1976); and a plasmid is apparently also involved in resistance to oxytetracycline in a strain of Streptomyces rimosus which produces it (Boronin \& Sadovnikova, 1972). Recently a second sex factor, SCP2, has been found in S. coelicolor A3(2) (Bibb, Freeman, \& Hopwood 1977) and a sex factor, SRP1, has been revealed in a strain of $S$. rimosus (Friend, Warren \& Hopwood, 1978).

A second line of evidence was the consideration that antibiotic resistance in clinical isolates of eubacteria is usually due to plasmid-borne genes and it has been suggested (Walker \& Walker, 1970; Benveniste \& Davies, 1973) that such genes may have originated in the bacteria that produce the antibiotics, notably members of the genus Streptomyces, which synthesize the majority of all known antibiotics (Bérdy, 1974), and may have been transferred to unrelated bacteria. The main argument for this theory is the presence of similar antibiotic-inactivating enzymes in antibiotic-producing streptomycetes and in resistant eubacteria (Benveniste \& Davies, 1973; El-Kersch \& Plourde, 1976; Shaw \& Hopwood, 1976; Nakano et al., 1977). Although this theory does not require the genes to be permanently plasmid-linked in their original streptomycete hosts, their dissemination to other bacteria might have been facilitated if this had been the case.

As a preliminary approach to the problem (Freeman, 1976) we determined the level of resistance of about 40 streptomycete strains, chosen essentially at random from various culture collections, to a series of 25 antibiotics and other antimicrobial agents, giving some 1000 tests. Some strains were relatively resistant to the majority of the growth inhibitors while some inhibitors were inactive against all, or nearly all, of the strains. We selected for study four cases in which a particular strain was significantly more resistant to a certain antibiotic than were most of the strains, since such behaviour might be expected if an extrachromosomal element, not uniformly present in the set of cultures, conferred some resistance to an antibiotic.

* Present address: Research Laboratory, Bass Production Ltd, High Street, Burton-on-Trent, Staffordshire DE14 1JZ. 
Suggestive preliminary evidence for extrachromosomal determination of resistance was then sought by testing each of the four strains for the frequent occurrence of colonies which had become more sensitive to the antibiotic in question. One of the four examples, in the genetically well-known $S$. coelicolor A3(2), was subjected to detailed genetic analysis which suggested that some transposable, possibly extrachromosomal, factor affected chloramphenicol resistance (Freeman, Bibb \& Hopwood, 1977); data on the other three examples - streptomycin resistance in Streptomyces griseus and S. glaucescens and erythromycin/chloramphenicol resistance in Streptomyces acrimycini-are described here.

\section{METHODS}

Strains. Of the 40 strains in the preliminary survey (Freeman, 1976), four were studied in detail: S. coelicolor A3(2); S. griseus (Collection of the University of Bradford no. 609, also known as Waksman 3475); $S$. acrimycini (Istituto Patologia Vegetale, Milan, no. 1610); and S. glaucescens (E.T.H., Zürich, no. 22794).

Cultural methods. Complete (CM) and minimal medium (MM) and general methods were those described by Hopwood (1967). In some experiments, glycerol $(1 \%, v / v)$ was substituted for glucose as carbon source in case some form of catabolite repression affected antibiotic resistance, but no obvious evidence for this was found. Stock cultures were grown on $\mathrm{CM}$ at $30^{\circ} \mathrm{C}$ and stored at $4{ }^{\circ} \mathrm{C}$, or suspensions of mycelial fragments and spores were stored in $20 \%$ (v/v) glycerol at $-17^{\circ} \mathrm{C}$. Ultraviolet (u.v.) irradiation was to a survival of about $1 \%$.

Preliminary tests for antibiotic resistance. These were made by measuring zones of growth inhibition (on lawns of each strain on MM containing glycerol) produced by antibiotic test discs (Mast Laboratories, Liverpool) containing known amounts of each of 25 antibiotics or antimicrobial agents. In some cases, when growth of the lawn was slow, the plates were pre-incubated for $24 \mathrm{~h}$ before receiving the test discs.

Isolation of antibiotic-sensitive variants. The three strains grew almost without inhibition on MM containing the following levels of antibiotic: $S$. griseus, $10 \mu \mathrm{g}$ streptomycin sulphate $\mathrm{ml}^{-1}$ (Glaxo Laboratories); S. acrimycini, $2 \mu \mathrm{g}$ erythromycin $\mathrm{ml}^{-1}$ (Sigma); S. glaucescens, $1 \mu \mathrm{g}$ streptomycin sulphate $\mathrm{ml}^{-1}$. Sensitive isolates, which arose spontaneously and after u.v. irradiation, were obtained by plating spores on CM at dilutions that gave well separated colonies and then replicating these colonies, when they were well sporulated, to MM containing the appropriate concentration of antibiotic. Colonies that failed to grow on replication were streaked on MM and re-tested. Most were confirmed as being antibiotic-sensitive.

\section{RESULTS}

Antibiotic-sensitive variants occurred spontaneously in all three strains at frequencies between about $0 \cdot 1$ and $1 \%$; after u.v. irradiation the frequency range was increased by a factor of 10 (Table 1). The frequencies of origin of streptomycin-sensitive $\left(\mathrm{Sm}^{\mathrm{s}}\right)$ variants of $S$. griseus and $S$. glaucescens and of erythromycin-sensitive $\left(\right.$ Ery $\left.^{\mathrm{S}}\right)$ variants of S. acrimycini were remarkably similar and also resembled those of chloramphenicol-sensitive $\left(\mathrm{Cml}^{\mathrm{s}}\right)$ variants in the two closely related strains $S$. coelicolor A3(2) and $S$. lividans 66 (Freeman et al., 1977).

In a study initiated with a different objective, Wright \& Hopwood (1977) found that the same strain of $S$. acrimycini gave rise to $\mathrm{Cml}^{\mathrm{s}}$ variants at a similar frequency (e.g. $1 \%$ spontaneously and $4 \%$ after u.v. irradiation) to that of Ery ${ }^{\mathrm{s}}$ variants in the present work. In a further experiment, we therefore sought variants that were sensitive to either of these antibiotics, or both. Out of 18 such variants, 16 were Ery ${ }^{\mathrm{s}} \mathrm{Cml}^{\mathrm{s}}$, two were Ery ${ }^{\mathrm{R}} \mathrm{Cml}^{\mathrm{s}}$ and none was Ery ${ }^{\mathrm{s}} \mathrm{Cml}^{\mathrm{R}}$.

The antibiotic-sensitive strains proved difficult to preserve. Of $17 \mathrm{Sm}^{9}$ derivatives of $S$. glaucescens, eight were found on subculture to have produced $\mathrm{Sm}^{\mathrm{R}}$ colonies. Four of the subcultures consisted almost entirely of $\mathrm{Sm}^{\mathrm{R}}$ colonies; the remainder gave mixtures of $\mathrm{Sm}^{\mathrm{s}}$ and $\mathrm{Sm}^{\mathrm{R}}$ colonies. Re-streaking an $\mathrm{Sm}^{\mathrm{S}}$ colony from such a mixture gave rise to a pure $\mathrm{Sm}^{\mathrm{S}}$ subculture. Instability was also observed with the $\mathrm{Sm}^{\mathrm{s}}$ S. griseus and Ery ${ }^{\mathrm{s}}$ S. acrimycini cultures; both required continued re-purification.

In $S$. coelicolor A3(2) and $S$. lividans 66 , revertibility of the $\mathrm{Cml}^{\mathrm{s}}$ to the $\mathrm{Cml}^{\mathrm{R}}$ phenotype showed that permanent loss of an extrachromosomal element could not explain the 
Table 1. Origin of antibiotic-sensitive variants in three streptomycetes

$\begin{array}{lccc}\text { Treatment } & \overbrace{\text { Antibiotic- }}^{\text {Total }} & \begin{array}{c}\text { Antibiotic- } \\ \text { sensitive }\end{array} & \begin{array}{c}\text { Anber of colonies } \\ \text { sensitive (\%) }\end{array} \\ \text { Streptomycin sensitivity } & \text { in } S \text {. griseus cub609 } & \\ \text { Control } & 1143 & 2 & 0.2 \\ \text { u.v. } & 2500 & 44 & 1.8 \\ \text { u.v. } & 95 & 10 & 10.5\end{array}$

(b) Erythromycin sensitivity in S. acrimycini IPV1610

$\begin{array}{lccr}\text { Control } & 1943 & 12 & 0.6 \\ \text { u.v. } & 1250 & 65 & 5.2 \\ \text { Control } & 921 & 0 & <0.1 \\ \text { u.v. } & 995 & 7 & 0.7\end{array}$

(c) Streptomycin sensitivity in S. glaucescens ЕTH22794

$\begin{array}{lrrr}\text { Control } & 2889 & 8 & 0 \cdot 3 \\ \text { u.v. } & 1211 & 35 & 2 \cdot 9 \\ \text { Control } & 550 & 2 & 0 \cdot 4 \\ \text { u.v. } & 1130 & 30 & 2 \cdot 7 \\ \text { u.v. } & 350 & 39 & 11 \cdot 1\end{array}$

(d) Streptomycin sensitivity in $\mathrm{Sm}^{\mathrm{R}}$ revertants from an $\mathrm{Sm}^{\mathrm{S}}$ variant of S. glaucescens ETH 22794

$\begin{array}{llll}\text { u.v. } & 213 & 10 & 4 \cdot 7 \\ \text { u.v. } & 269 & 14 & 5 \cdot 2\end{array}$

$\mathrm{Cml}^{\mathrm{R}} \rightarrow \mathrm{Cml}^{\mathrm{s}}$ transition, even though segregation of $\mathrm{Cml}^{\mathrm{s}}$ versus $\mathrm{Cml}^{\mathrm{R}}$ in crosses was incompatible with simple chromosomal linkage. We therefore attempted to characterize the revertibility or otherwise of the $\mathrm{Sm}^{\mathrm{s}}$ and Erys phenotypes. Two sensitive variants of each of the three species were studied by plating spores on antibiotic-containing plates. In $S$. glaucescens, one of the $\mathrm{Sm}^{\mathrm{S}}$ variants yielded $\mathrm{Sm}^{\mathrm{R}}$ colonies at reproducible frequencies of about $10^{-5}$ spontaneously and $10^{-4}$ after u.v. irradiation, and two of the $\mathrm{Sm}^{\mathrm{R}}$ revertants yielded $\mathrm{Sm}^{\mathrm{s}}$ colonies again at frequencies of 4 to $5 \%$ after u.v. irradiation (Table 1); thus the $\mathrm{Sm}^{\mathrm{s}}$ 'mutation' in this strain appeared to be truly reversible. The second $\mathrm{Sm}^{\mathrm{s}}$ variant failed to revert (detection level, $10^{-6}$ spontaneously and $10^{-5}$ after u.v.).

In $S$. griseus, the two $\mathrm{Sm}^{\mathbb{S}}$ variants gave $\mathrm{Sm}^{\mathrm{R}}$ colonies at frequencies of about $10^{-6}$, both spontaneously and after u.v. irradiation. However, two $\mathrm{Sm}^{\mathrm{R}}$ 'revertants' failed to yield $\mathrm{Sm}^{\mathrm{s}}$ variants $(<0.3 \%)$ after u.v. irradiation. Thus true reversal of the original $\mathrm{Sm}^{\mathrm{s}}$ 'mutation' was not involved. In the case of $\operatorname{Ery}^{\mathbb{S}}\left(\mathrm{Cml}^{\mathbb{S}}\right)$ variants of $S$. acrimycini, background growth on plates containing erythromycin or chloramphenicol prevented the selection of possible Ery $^{\mathrm{R}}\left(\right.$ or $\mathrm{Cml}^{\mathrm{R}}$ ) colonies.

\section{DISCUSSION}

The most striking aspect of the results of this survey is the finding that, in all four of the chosen cases in which a strain exhibited a higher level of resistance to an antibiotic than the majority of strains, this resistance was found to be unstable. Since selection of the four cases was, to a considerable extent, arbitrary, it is very likely that many more examples were present in the original matrix of tests. In two of the chosen examples $-S$. coelicolor (and $S$. lividans) and $S$. glaucescens - there was an oscillation between resistance and sensitivity, at least in a proportion of occurrences, with a much higher frequency of $R \rightarrow S$ than of $S \rightarrow R$ events. In the other two examples, true reversal of the $\mathbf{R} \rightarrow \mathbf{S}$ event was not demonstrated, although it was not excluded.

Another example of unstable antibiotic resistance has recently been published (Shaw \& 
Piwowarski, 1977); $\mathrm{Sm}^{\mathrm{s}}$ variants of $S$. bikiniensis arose with high frequencies after acriflavine or ethidium bromide treatment (many of them also failed to synthesize streptomycin). The $\mathrm{Sm}^{\mathrm{s}}$ variants were not highly unstable - they remained sensitive after six transfers - but no attempt to select rare $\mathrm{Sm}^{\mathrm{R}}$ 'revertants' was described. In another report, an unnamed Streptomyces $\mathrm{sp}$. was found to give rise to frequent $\beta$-lactamase non-producing variants after acriflavine treatment, although they were apparently not more sensitive than the original strain to $\beta$-lactam antibiotics (Ogawara \& Nozaki, 1977).

All these results point to the presence in many streptomycetes of determinants of antibiotic resistance which can be inactivated or lost with high frequency. Much more detailed studies will be required in order to understand the genetic mechanisms involved. Even in $S$. coelicolor A3(2), with a comparatively well-developed experimental genetic system, it has not yet been possible to provide a detailed model of the $\mathrm{Cml}^{\mathrm{R}} \rightarrow \mathrm{Cml}^{\mathrm{s}} \rightarrow \mathrm{Cml}^{\mathrm{R}}$ oscillation, although it seems probable that some kind of transposition of genetic material is involved, rather than its permanent loss (Freeman et al., 1977). The $\mathrm{Sm}^{\mathrm{R}} \rightarrow \mathrm{Sm}^{\mathrm{S}} \rightarrow \mathrm{Sm}^{\mathrm{R}}$ oscillation in S. glaucescens seems to be similar, although the genetic system in this strain (Baumann \& Kocher, 1976) has not yet been used to analyse it.

In summary, none of the examples of unstable antibiotic resistance described in this paper can be completely explained by simple loss of a plasmid, since return to resistance could always take place (albeit in certain cases not by a true reversion of the change to sensitivity). It is, of course, possible that more than one mechanism is at work in different strains. Certain other cases of frequent origin of sensitive strains may well involve genuine plasmid loss: A. M. Boronin has recently found (personal communication) extrachromosomal DNA in his $S$. rimosus strain which is absent from the oxytetracycline-sensitive variants. Moreover, in $S$. coelicolor A3(2), simple loss of the SCP1 plasmid certainly gives rise to methylenomycin sensitivity. It may be significant that in these two examples, resistance is in respect of the organism's own antibiotic.

Detailed analysis of several of these systems involving antibiotic resistance may very well illuminate the many poorly documented examples of 'instability' of desirable characteristics which plague strain improvement programmes in industrial fermentations.

We are very grateful to $\mathrm{Dr} \mathrm{T}$. Cross, University of Bradford, who generously provided strains from his CUB collection. R.F.F. gratefully acknowledges a postgraduate studentship from the Science Research Council.

\section{REFERENCES}

Aragawa, H., Okanishi, M. \& Umezawa, H. (1975). A plasmid involved in chloramphenicol production in Streptomyces venezuelae: evidence from genetic mapping. Journal of General Microbiology 90, 336-346.

Baumann, R. \& Kocher, H. P. (1976). Genetics of Streptomyces glaucescens and regulation of melanin production. In Second International Symposium on the Genetics of Industrial Microorganisms, pp. 535-551. Edited by K.D. Macdonald. London and New York: Academic Press.

Benveniste, R. \& Davies, J. (1973). Aminoglycoside antibiotic-inactivating enzymes in actinomycetes similar to those present in clinical isolates of antibiotic-resistant bacteria. Proceedings of the National Academy of Sciences of the United States of America 70, 2276-2280.

BÉRDY, J. (1974). Recent developments of antibiotic research and classification of antibiotics according to chemical structure. Advances in Applied Microbiology 18, 309-406.
Bibb, M. J., Freeman, R. F. \& Hopwood, D. A. (1977). Physical and genetical characterisation of a second sex factor, SCP2, for Streptomyces coelicolor A3(2). Molecular and General Genetics 154, 155-166.

Boronin, A. M. \& SAdovnikova, I. G. (1972). Elimination by acridine dyes of oxytetracycline resistance in Actinomyces rimosus. Genetika 8, 174-176.

El-Kersch, T. A. \& Plourde, J. R. (1976). Biotransformation of antibiotics. I. Acylation of chloramphenicol by spores of Streptomyces griseus isolated from the Egyptian soil. Journal of Antibiotics, Japan 24, 292-302.

Freeman, R. F. (1976). Studies of antibiotic resistance and production in Streptomyces. Ph.D. thesis, University of East Anglia, Norwich.

Freeman, R. F., BibB, M. J. \& Hopwood, D. A. (1977). Chloramphenicol acetyltransferaseindependent chloramphenicol resistance in Streptomyces coelicolor A3(2). Journal of General Microbiology 98, 453-465. 
Friend, E. J., Warren, M. \& Hopwood, D. A. (1978). Genetic evidence for a plasmid controlling fertility in an industrial strain of Streptomyces rimosus. Journal of General Microbiology 106, 201-206.

Gregory, K. F. \& Huang, J. C. C. (1964). Tyrosinase inheritance in Streptomyces scabies. I. Genetic recombination. Journal of Bacteriology 87, 1281-1286.

Hopwoon, D. A. (1967). Genetic analysis and genome structure in Streptomyces coelicolor. Bacteriological Reviews 31, 373-403.

KÄHLER, R. \& NoACK, D. (1974). Action of acridine orange and ethidium bromide on growth and antibiotic activity of Streptomyces hygroscopicus JA6599. Zeitschrift für allgemeine Mikrobiologie 14, 529-533.

KirbY, R., Wright, L. F. \& Hopwood, D. A. (1975). Plasmid-determined antibiotic synthesis and resistance in Streptomyces coelicolor. Nature, London 254, 265-267.

Nakano, H., Matsuhashi, Y., Takeuchi, T. \& UMEZAWA, H. (1977). Distribution of chloramphenicol acetyltransferase and chloramphenicol-3-acetate esterase among Streptomyces and Corynebacterium. Journal of Antibiotics, Japan 30, 76-82.

Ogawara, H. \& NozaKI, S. (1977). Effect of acriflavine on the production of $\beta$-lactamase in Streptomyces. Journal of Antibiotics, Japan 30, 337-339.

OKanishi, M., OHTA, T. \& UMezaWa, H. (1970).
Possible control of formation of aerial mycelium and antibiotic production in Streptomyces by episomic factors. Journal of Antibiotics, Japan 23, 45-47.

Redshaw, P. A., McCann, P. A., Sankaran, L. \& Pogell, B. M. (1976). Control of differentiation in streptomycetes: involvement of extrachromosomal deoxyribonucleic acid and glucose repression in aerial mycelia development. Journal of Bacteriology 125, 698-705.

SHAw, W. V. \& Hopwood, D. A. (1976). Chloramphenicol acetylation in Streptomyces. Journal of General Microbiology 94, 159-166.

Shaw, P. D. \& Piwowarski, J. (1977). Effects of ethidium bromide and acriflavine on streptomycin production by Streptomyces bikiniensis. Journal of Antibiotics, Japan 30, 404-408.

WALKer, M. S. \& WALKER, J. B. (1970). Streptomycin biosynthesis and metabolism. Enzymatic phosphorylation of dihydrostreptobiosamine moieties of dihydrostreptomycin-(streptidino) phosphate and dihydrostreptomycin by Streptomyces extracts. Journal of Biological Chemistry 245, 6683-6689.

WRIGHT, L. F. \& HoPwood, D. A. (1976). Identification of the antibiotic determined by the SCP1 plasmid of Streptomyces coelicolor A3(2). Journal of General Microbiology 95, 96-106.

WRIGHT, H. M. \& HoPwOOD, D. A. (1977). A chromosomal gene for chloramphenicol acetyltransferase in Streptomyces acrimycini. Journal of General Microbiology, 102, 417-421. 